\title{
Computational Study of Triterpenoids of Ganoderma lucidum with Aspartic Protease Enzymes for Discovering HIV-1 and Plasmepsin Inhibitors
}

\author{
Devinna Kang ${ }^{1}$, Mutakin Mutakin ${ }^{1} \&$ Jutti Levita $^{1}$ \\ ${ }^{1}$ Department of Pharmaceutical Analysis and Medicinal Chemistry, Faculty of Pharmacy, Padjadjaran University, \\ Jl. Raya Bandung-Sumedang Km.21 Jatinangor Sumedang, West Java 45363, Indonesia \\ Correspondence: Jutti Levita, Department of Pharmaceutical Analysis and Medicinal Chemistry, Faculty of \\ Pharmacy, Padjadjaran University, Jl. Raya Bandung-Sumedang Km.21 Jatinangor Sumedang, West Java 45363, \\ Indonesia. Tel: 622-2779-6200. E-mail: jutti.levita@unpad.ac.id
}

Received: December 18, 2014

Accepted: January 21, 2015 Online Published: February 3, 2015

doi:10.5539/ijc.v7n1p62

URL: http://dx.doi.org/10.5539/ijc.v7n1p62

\begin{abstract}
Rapid resistance development of HIV-1 and Plasmodium falciparum parasite requires discovery of more potent new drugs. Aspartic protease enzymes expressed by HIV-1 and P. falciparum could be used as important drug targets. The catalytic site is located at the bottom of a cleft in the enzyme surface and consists of triad Asp25, Thr26, Gly27. Important aspartic acids are Asp32 and Asp215. Aspartic proteases are inhibited by pepstatin-A, a naturally occurring peptide containing two statins, which replace the amino acids. The hydroxyl group of the statin binds tightly to the catalytically-active aspartic acid residues in the active site of protease, thereby mimicking the transition state of the peptide cleavage. Previous study proved that ganoderiol-F, a triterpenoid isolated from the stem of Ganoderma sinense showed higher affinity towards HIV-1 protease (binding energy= $-11.40 \mathrm{kcal} / \mathrm{mol}$ and $\mathrm{K}_{\mathrm{i}}=4.68 \mathrm{nM}$ ) than to plasmepsin I (binding energy= $-9.96 \mathrm{kcal} / \mathrm{mol}$ and $\mathrm{K}_{\mathrm{i}}=50.94 \mathrm{nM}$ ). In this paper, computational studies of G. lucidum triterpenoids with aspartic protease enzymes of HIV-1 and plasmepsin I, were performed using AutoDock 4.2. Nelfinavir and KNI-10006 were used as the standards for HIV-1 protease and plasmepsin I, respectively. The four triterpenoids are able to interact with both enzymes. Ganoderat acid-B showed the best affinity to HIV-1 protease (binding energy $=-7.49 \mathrm{kcal} / \mathrm{mol}$ and $\mathrm{Ki}=0.001$ $\mathrm{mM}$ ) which is better than nelfinavir. Furthermore, the best affinity to Plasmepsin I is showed by ganodermanondiol (binding energy $=-7.14 \mathrm{kcal} / \mathrm{mol}$ and $\mathrm{Ki}=0.005 \mathrm{mM}$ which is better than KNI-10006. According to the values of binding energy and inhibition constant, triterpenoids of G. lucidum could be developed further as both anti-HIV and anti-malaria.
\end{abstract}

Keywords: Aspartic proteases; HIV-1; Malaria; Ganoderma lucidum; Plasmepsin I

\section{Introduction}

AIDS and malaria are health problems that occur in many parts of the world. According to WHO and UNAIDS, 35 million people are globally living with HIV at the end of 2013. That same year, 2.1 million people became newly infected, and 1.5 million died of AIDS-related causes. Furthermore, in 2012 malaria caused an estimated 627000 deaths (WHO, 2014).

Aspartic proteases play key roles in the biology of malaria parasites and human immunodeficiency virus type 1 (HIV-1). Parikh and colleagues tested the activity of seven HIV-1 protease inhibitors against cultured $P$. falciparum. All compounds inhibited the development of parasites at pharmacologically relevant concentrations. These findings suggest that use of HIV-1 protease inhibitors may offer clinically relevant antimalarial activity (Parikh et al, 2005). This inhibition may occur due to aspartic proteases, e.g. Plasmepsin I (PM I), present in the food vacuole of P. falciparum. PM I, II, and IV and histo-aspartic protease encode hemoglobin-degrading food vacuole proteases. Despite having a histidine in place of one of the catalytic aspartic acids conserved in other aspartic proteases, histo-aspartic protease is an active hydrolase. A bioinformatic analysis has demonstrated that $P$. falciparum PM II, which is similar to the secretory aspartic protease 2 of Candida albicans (the first nonretroviral microrganism proven to be susceptible to PMs is one of the eukaryotic proteases that most resemble the HIV-1 protease (Baneerje et al, 2002; Savarino et al, 2005). 
The protein is composed of three regions, the catalytic core domain (Asp25, Gly27, Ala28, Asp29, and Asp30), flap (Ile47, Gly48, Gly49, and Ile50), and the C-terminal region (Pro81 and Ile84). The amino acid residues of catalytic core are known to be highly conserved residues to which a potent inhibitor may bind strongly (Hou, 2008).

Previous study proved that ganoderiol-F, a triterpenoid isolated from the stem of Ganoderma sinense showed higher affinity towards HIV-1 protease (binding energy $=-11.40 \mathrm{kcal} / \mathrm{mol}$ and $\mathrm{K}_{\mathrm{i}}=4.68 \mathrm{nM}$ ) than to plasmepsin I (binding energy $=-9.96 \mathrm{kcal} / \mathrm{mol}$ and $\mathrm{K}_{\mathrm{i}}=50.94 \mathrm{nM}$ ) (Levita, 2014). In vitro studies showed that triterpenoid compounds from G. lucidum, e.g. ganolucidic acid-A, ganoderat acid-B, ganoderat acid- $\beta$ and ganodermanondiol, exerted anti-HIV activity with $\mathrm{IC}_{50}$ values of $70,170,20$ and $90 \mu \mathrm{M}$, respectively (Northrop, 2001). To examine the interaction and activity of the compounds, molecular docking was performed. Docking results then were compared with the standards, that are Nelfinavir and KNI-10006.

\section{Materials and methods}

\subsection{Materials}

Personal computer operated by Windows Vista, Intel ${ }^{\circledR}$ Core $^{\mathrm{TM}} \quad$ Intel ${ }^{\circledR} \quad$ Core $^{\mathrm{TM}} 2$ Duo P8400@ $2.26 \mathrm{GHz}$, 32-bit, harddisk $222 \mathrm{~GB}$, and RAM memory 4.00 GB.

Softwares used were:

(1) ChemBioDraw ${ }^{\circledR}$ Ultra 13.0 free trial supported by Cambridge Soft Corporation (www.cambridgesoft.com), to draw the 2D structure of the ligands

(2) Hyperchem Professional 8.0 (10 days usage, verification code: 0-36279), supported by Hypercube Incorporation (www.hyper.com), for geometry optimization and analysis of ligand properties.

(3) Swiss-PdbViewer 4.1 (http://spdbv.vital-it.ch), to repair the incomplete crystallized structures and to separate receptor monomer.

(4) Ligand Explorer (available at http://www.pdb.org/pdb/explore), to visualize the interactions of bound ligands in protein structures.

(5) AutoDock 4.2 (downloaded from http://autodock.scrips.edu) for molecular docking process.

(6) OpenBabel GUI (downloaded from http://openbabel.org), to convert the file format throughout the research.

\subsection{Methods}

\subsubsection{Preparation of HIV-1 PR (PDB code: 3EKX) and PM I (PDB code: 3QS1)}

a. Three dimensions enzyme structures used in this research, HIV-1 PR (PDB code: 3EKX, resolution: 1.97 $\AA$ ), and PM I (PDB code: 3QS1, resolution: $3.1 \AA$ ), were downloaded from Protein Data Bank (www.pdb.org) database online.

b. HIV-1 PR and PM I monomers were separated from the protein using Swiss-Pdb Viewer 4.1.

c. Active sites of HIV-1 PR and PM I were analyzed by using Q-SiteFinder and Discovery Studio v.3.5

2.2.2 Preparation of the Ligands

Ganolucidic acid-A, ganoderat acid-B, ganoderat acid- $\beta$ and ganodermanondiol were produced by ChemBioDraw Ultra 13.0 free trial.

a. Geometry optimizations were done using HyperChem v.8.0 with force field semi empirical PM3 method, Polak-Ribiere (conjugate gradient) algorithm.

b. Each molecule was analyzed with QSAR (quantitative structure-activity relationship) parameters and the electrostatic potential properties.

\subsubsection{Validation}

a. Nelfinavir structure (produced by ChemBioDraw Ultra 13.0) was superimposed with crystallized nelfinavir structure (obtained from PDB) using HyperChem Professional 8.0.

b. Both nelfinavir and KNI-10006 (produced by ChemBioDraw Ultra 13.0) were redocked to HIV-1 PR and PM I with 20 times iteration using AutoDock 4.2.

\subsubsection{Docking of Ligands to HIV-1 PR and PM I}

a. Ligands (ganolucidic acid-A, ganoderat acid-B, ganoderat acid- $\beta$ and ganodermanondiol) were docked in the active sites of HIV-1 PR and PM I. 
b. Results were analyzed using association coefficient (Cramer's V), agreement and inter-rater reliability (Cohen's Kappa).

\section{Results and Discussion}

HIV-1 PR (PDB code: 3EKX) enzyme, a homodimer, was isolated from Homo sapiens with resolution $1.97 \AA$ (King, 2012). Active binding site volume is $341 \AA^{3}$. The position of this site lies between 9, 19, 4 (x,y, z) and 25, 43, $25(\mathrm{x}, \mathrm{y}, \mathrm{z})$.

PM I (PDB code: 3QS1) enzyme, a homotetramers that consists of chain A, B, C, and D, was isolated from $P$. falciparum with resolution $3.10 \AA^{3}$ (Bhaumik, 2011). Active binding site volume is $249 \AA$. The position of this site lies between 20, -17, -3 (x, y, z) and 41, -1, 12 (x, y, z).

The ligands were analyzed by employing HyperChem Professional 8.0. The results are shown in Table 1. The most lipophylic compound is ganodermanondiol, which is shown by the highest Log P value (6.45). It is obvious that the lipophylicity is caused by its less HB donors and acceptors when compared to the others. Ganodermanondiol has two hydroxyls and one carbonyl.

Table 1. Ligand Properties

\begin{tabular}{|c|c|c|c|c|c|}
\hline Ligand & Energy $(\mathrm{kcal} / \mathrm{mol})$ & $\log P$ & $\begin{array}{l}\text { Volume } \\
\qquad\left(\AA^{3}\right)\end{array}$ & $\begin{array}{l}\text { Massa } \\
(\mathrm{amu})\end{array}$ & $\begin{array}{c}\text { Electrostatic potential map } \\
\text { [calculated using HyperChem] }\end{array}$ \\
\hline Ganolucidic acid-A & -8070.4512 & 5.72 & 1335.27 & 500.68 & \\
\hline Ganoderat acid-B & -8158.5932 & 4.80 & 1364.70 & 516.67 & \\
\hline Ganoderat acid- $\beta$ & -8060.0440 & 5.45 & 1348.03 & 500.68 & \\
\hline Ganodermanondiol & -7981.6760 & 6.45 & 1322.31 & 456.71 & (twe) \\
\hline
\end{tabular}

Validation was performed by overlaying structures resulted RMS error value $0,3840 \AA$, it means programs that used for drawing and geometry optimizing (ChemBioDraw Ultra 13.0 free trial and HyperChem v.8.0) are valid.

All ligands are located in the catalytic site of HIV-1 PR. The binding modes is similar with nelvinafir, a known inhibitor of HIV-1 PR. Ganolucidic acid A (Fig.1a), ganoderat acid B (Fig.1b) and ganodermanondiol (Fig.1d) interact via three hydrogen bonds, while ganoderat acid $\beta$ (Fig.1c) and nelfinavir (Fig.1e) showed two hydrogen bonds. According to the predicted Ki of the ligands, ganoderat acid B showed better affinity towards HIV-1 PR than nelfinavir (Table 2). It could be predicted that ganolucidic acid A, ganoderat acid B, ganoderat acid $\beta$, and ganodermanondiol inhibit the substrates of protease competitively (Fig.1).

These results are suitable with the statement Jaskolski et al (1991) that the catalytic site consists of triad Asp25,Thr26,Gly27 and protease substrates interact directly with the aspartic acid residues of each monomer to catalyze the reaction (Jaskolski, 1991). 
Table 2. Docking of Ligands on HIV-1 PR

\begin{tabular}{|c|c|c|c|}
\hline Ligand & $\begin{array}{c}\mathrm{Ei} \\
(\mathrm{kcal} / \mathrm{mol})\end{array}$ & $\begin{array}{c}\mathrm{Ki} \\
(\mathrm{mM})\end{array}$ & Hydrogen Interaction \\
\hline Ganolucidic acid A & -5.55 & 0.086 & $\begin{array}{l}\operatorname{HIV~N~}(\mathrm{H}) \rightarrow \mathrm{H}(\mathrm{O}) \operatorname{Arg} 8(1.739 \AA) \\
\operatorname{HIV~N}(\mathrm{H}) \rightarrow \mathrm{H}(\mathrm{O}) \operatorname{Arg} 8(1.752 \AA) \\
\text { GA O }(\mathrm{H}) \rightarrow \mathrm{H}(\mathrm{O}) \operatorname{Gly} 27(1.939 \AA)\end{array}$ \\
\hline Ganoderat acid B & -7.49 & 0.001 & $\begin{array}{l}\text { GB O }(\mathrm{H}) \rightarrow \mathrm{H}(\mathrm{O}) \operatorname{Asp} 25(1.703 \AA) \\
\mathrm{HIV} \mathrm{N}(\mathrm{H}) \rightarrow \mathrm{H}(\mathrm{O}) \operatorname{Ile} 50(1.706 \AA) \\
\operatorname{HIV~O}(\mathrm{H}) \rightarrow \mathrm{H}(\mathrm{O}) \operatorname{Thr} 80(2.143 \AA)\end{array}$ \\
\hline Ganoderat acid $\beta$ & -4.22 & 0.810 & $\begin{array}{l}\operatorname{HIV~N~}(\mathrm{H}) \rightarrow \mathrm{H}(\mathrm{O}) \operatorname{Thr} 26(1.836 \AA) \\
\operatorname{HIV~N}(\mathrm{H}) \rightarrow \mathrm{H}(\mathrm{O}) \operatorname{Ile} 50(1.955 \AA)\end{array}$ \\
\hline Ganodermanondiol & -4.57 & 0.444 & $\begin{array}{l}\mathrm{GD} \mathrm{O}(\mathrm{H}) \rightarrow \mathrm{H}(\mathrm{O}) \operatorname{Asp} 25(2.165 \AA) \\
\mathrm{GD} \mathrm{O}(\mathrm{H}) \rightarrow \mathrm{H}(\mathrm{O}) \operatorname{Asp} 25(1.718 \AA) \\
\mathrm{HIV} \mathrm{O}(\mathrm{H}) \rightarrow \mathrm{H}(\mathrm{O}) \operatorname{Gly} 27(1.739 \AA)\end{array}$ \\
\hline $\begin{array}{l}\text { Nelfinavir } \\
\text { (re-docking) }\end{array}$ & -4.33 & 0.672 & $\begin{array}{l}\text { NEL O }(\mathrm{H}) \rightarrow \mathrm{H}(\mathrm{O}) \operatorname{Asp} 25(1.985 \AA) \\
\text { NEL O }(\mathrm{H}) \rightarrow \mathrm{H}(\mathrm{N}) \operatorname{Asp} 25(2.24 \AA)\end{array}$ \\
\hline
\end{tabular}

Table 3. Association Coefficient, Agreement and Inter-Rater Reliability Amino Acid of the Ligands with Nelfinavir

\begin{tabular}{lccc}
\hline \multirow{2}{*}{ Ligand } & \multicolumn{2}{c}{ Correlation* } & \multicolumn{1}{c}{ Proximity** } \\
\cline { 2 - 4 } & Cramer's V & P & Kappa \\
\hline Ganolucidic acid A & 0.55 & 0.008 & $0.55(95 \%$ CI:[0.20,0.90]) \\
Ganoderat acid B & 0.18 & 0.390 & $0.18(95 \%$ CI:[-0.23,0.59]) \\
Ganoderat acid $\beta$ & 0.28 & 0.190 & $0.27(95 \%$ CI:[-0.13,0.68]) \\
Ganodermanondiol & 0.46 & 0.027 & $0.45(95 \%$ CI:[0.08,0.83]) \\
\hline
\end{tabular}

* Relation coefficient was calculated based on Cramer's V association compared with the amino acid residues from re-docking of nelfinavir.

** Proximity is calculated based on Cohen's Kappa method compared with the amino acid residues from re-docking of nelfinavir.

Based on the statistical results, the compounds which have similar amino acid residues closest to nelfinavir are ganolucidic acid A and ganodermanondiol, results of p-value less than 0.05 indicates significant results. Cohen's Cappa measurement results for ganolucidic acid A and ganodermanondiol showed affinity with moderate levels of agreement. While the compound that least like is ganoderat acid $\beta$ and ganoderat acid $\mathrm{B}$, the resulting $\mathrm{p}$-value of more than 0.05 indicates that the result is not significant. Cohen's Cappa measurement results ganoderat acid $\beta$ showed affinity with fair level agreement and ganoderat acid B showed affinity with small level agreement.

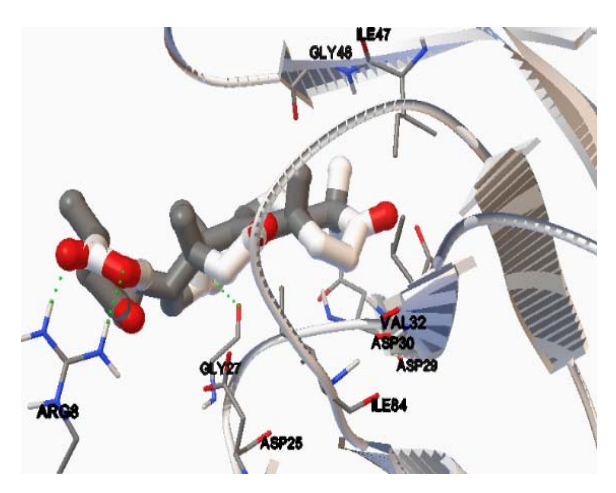

(a)

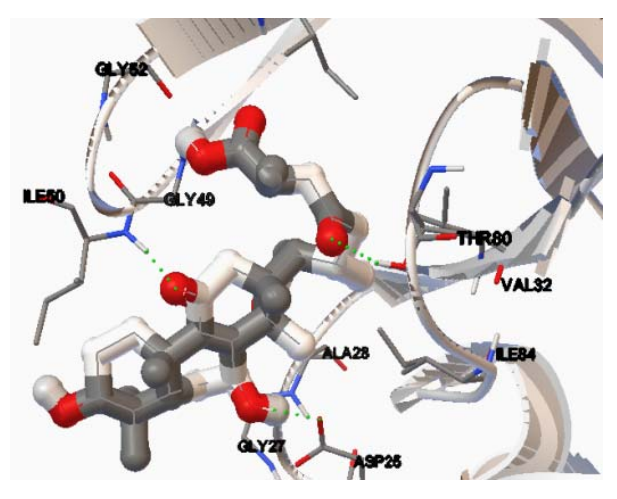

(b) 


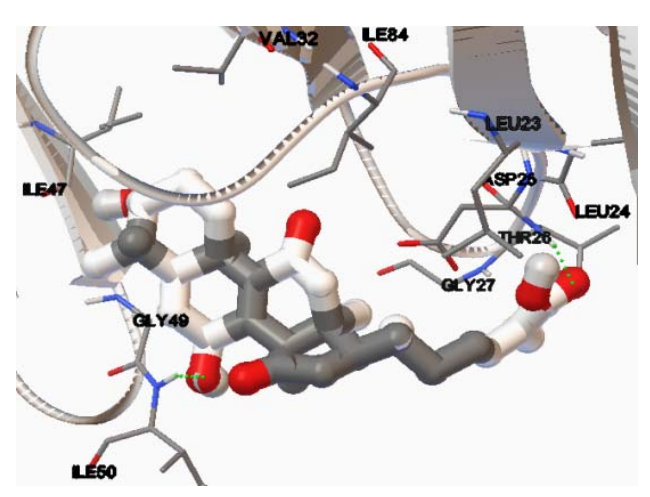

(c)

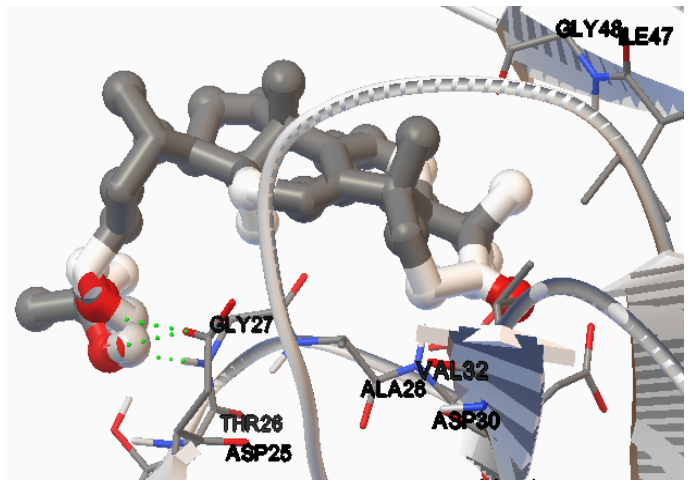

(d)

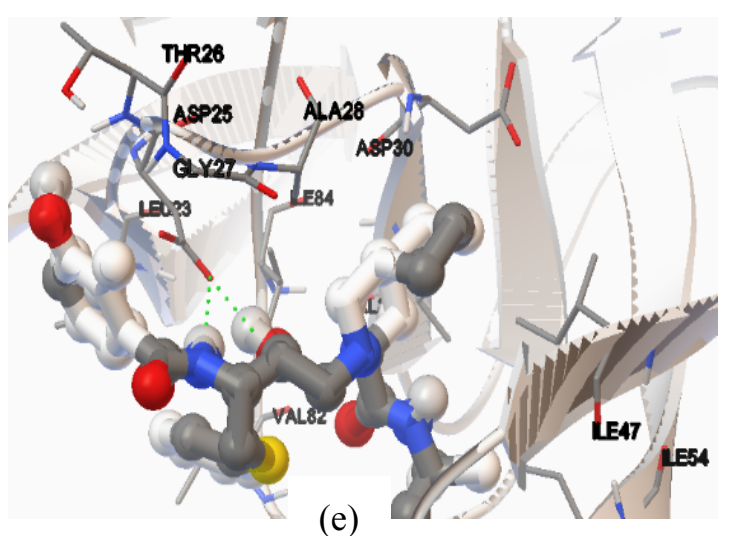

Figure 1. Docking results of ganolucidic acid A (a), ganoderat acid B (b), ganoderat acid $\beta$ (c), and ganodermanondiol (d), nelfinavir (e) on the active site of HIV-1 PR (PDB code: 3EKX).

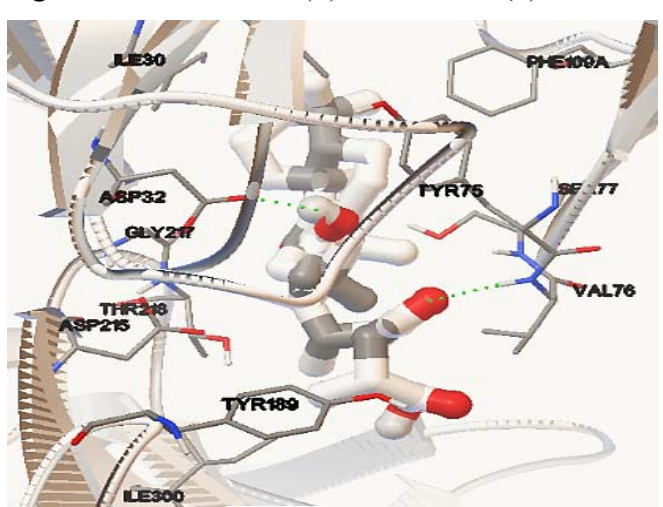

(a)

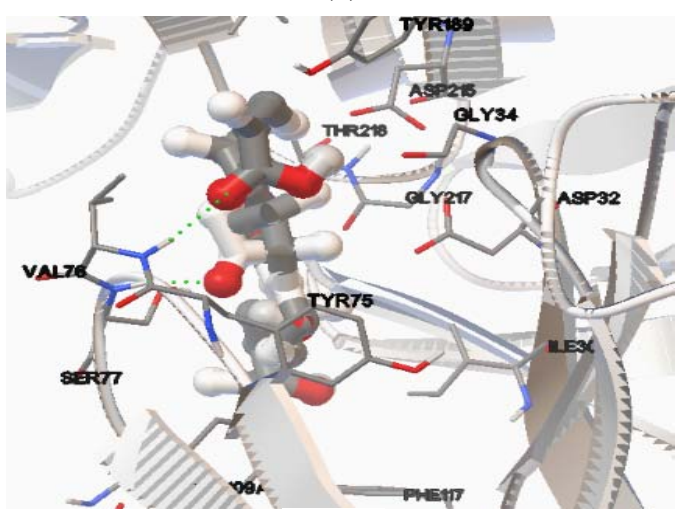

(c)

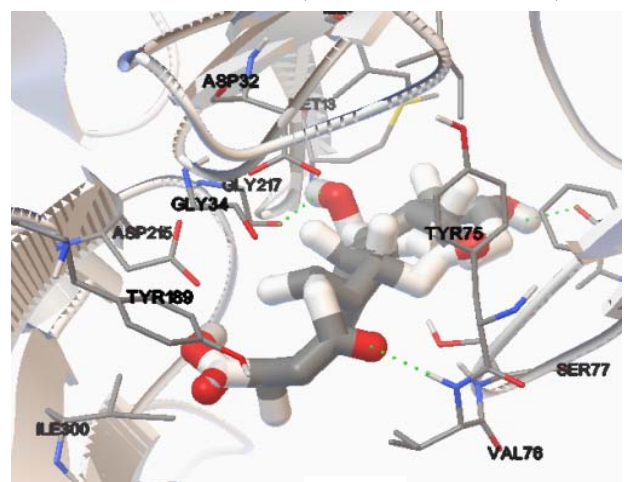

(b)

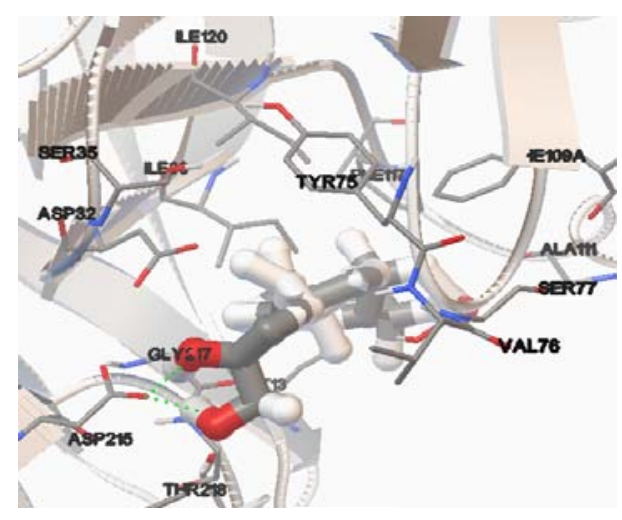

(d) 


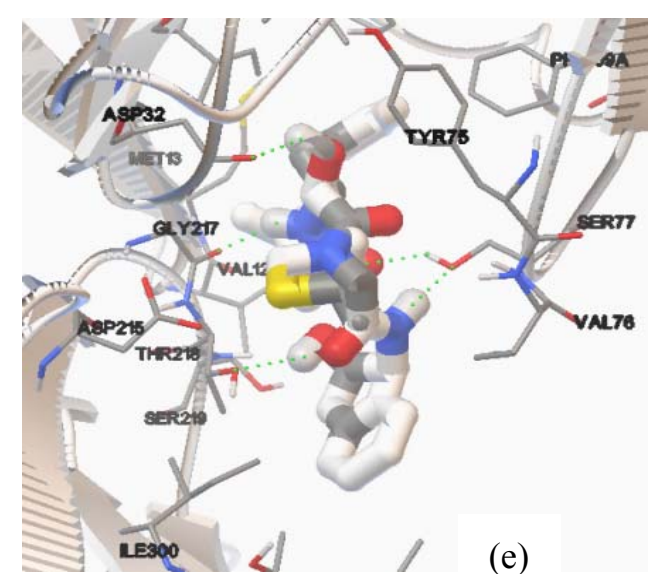

Figure 2. Docking results of ganolucidic acid A (a), ganoderat acid B (b), ganoderat acid $\beta(c)$, and ganodermanondiol (d), KNI-10006 (e) on the active site of PM I (PDB code: 3QS1)

All ligands are located in the catalytic site of PM I, as showed by the existence of two important aspartic acids, Asp32 and Asp215 (Fig.2). The binding modes is similar with KNI-10006, a known inhibitor of PM I. Protease substrates interact directly with aspartic acid residues of each monomer to catalyze the reaction, therefore, according to docking results, it could be predicted that ganolucidic acid A, ganoderat acid B, ganoderat acid $\beta$, and ganodermanondiol inhibit the substrates of protease competitively (Fig.2).

Ganoderat acid B interaction with PM I showed that it formed three hydrogen bonds (Fig. 2b Table 4), two bonds were formed between the ganolucidic acid A (Fig. 2a Table 4), ganoderat acid $\beta$ (Fig. 2c Table 4), ganodermanondiol with PM I (Fig. 2d Table 4), and five bonds were formed between the KNI-10006 with PM I (Fig. 2e Table 4). According to the predicted Ki of the ligands, ganodermanondiol showed better affinity towards PM I than KNI-10006 (Table 4).

Table 4. Docking of Ligands on PM I

\begin{tabular}{|c|c|c|c|}
\hline Ligand & $\begin{array}{c}\mathrm{Ei} \\
(\mathrm{kcal} / \mathrm{mol})\end{array}$ & $\begin{array}{c}\mathrm{Ki} \\
(\mathrm{mM})\end{array}$ & Hydrogen Interaction \\
\hline Ganolucidic acid A & -6.89 & 0.008 & $\begin{array}{l}\text { GA O }(\mathrm{H}) \rightarrow \mathrm{H}(\mathrm{O}) \operatorname{Asp} 32(1.924 \AA) \\
\text { PM1 N }(\mathrm{H}) \rightarrow \mathrm{H}(\mathrm{O}) \operatorname{Val} 76(2.13 \AA)\end{array}$ \\
\hline Ganoderat acid B & -5.42 & 0.105 & $\begin{array}{l}\mathrm{PM} 1 \mathrm{~N}(\mathrm{H}) \rightarrow \mathrm{H}(\mathrm{O}) \operatorname{Val} 76(2.061 \AA) \\
\mathrm{GB} \mathrm{O}(\mathrm{H}) \rightarrow \mathrm{H}(\mathrm{O}) \text { Ala111 }(1.823 \AA) \\
\mathrm{GB} \mathrm{O}(\mathrm{H}) \rightarrow \mathrm{H}(\mathrm{O}) \mathrm{Gly} 217(1.849 \AA)\end{array}$ \\
\hline Ganoderat acid $\beta$ & $-5,73$ & 0.063 & $\begin{array}{l}\text { PM1 N }(\mathrm{H}) \rightarrow \mathrm{H}(\mathrm{O}) \operatorname{Val} 76(2.217 \AA) \\
\text { PM1 N }(\mathrm{H}) \rightarrow \mathrm{H}(\mathrm{O}) \operatorname{Ser} 77(2.243 \AA)\end{array}$ \\
\hline Ganodermanondiol & -7.14 & 0.005 & $\begin{array}{l}\mathrm{GD} \mathrm{O}(\mathrm{H}) \rightarrow \mathrm{H}(\mathrm{O}) \operatorname{Asp} 215(1.879 \AA) \\
\mathrm{GD} \mathrm{O}(\mathrm{H}) \rightarrow \mathrm{H}(\mathrm{O}) \operatorname{Asp} 215(1.838 \AA)\end{array}$ \\
\hline $\begin{array}{l}\text { KNI-10006 } \\
\text { (re-docking) }\end{array}$ & -5.46 & 0.099 & $\begin{array}{l}\text { KNI O }(\mathrm{H}) \rightarrow \mathrm{H}(\mathrm{O}) \text { Asp32 } \\
\text { KNI O }(\mathrm{H}) \rightarrow \mathrm{H}(\mathrm{N}) \operatorname{Ser} 77 \quad(2.018 \AA) \\
\text { PM1 O }(\mathrm{H}) \rightarrow \mathrm{H}(\mathrm{O}) \operatorname{Ser} 77 \quad(1.876 \AA) \\
\mathrm{KNI} \mathrm{O}(\mathrm{H}) \rightarrow \mathrm{H}(\mathrm{O}) \mathrm{Gly} 217(2.085 \AA) \\
\mathrm{KNI} \mathrm{O}(\mathrm{H}) \rightarrow \mathrm{H}(\mathrm{O}) \operatorname{Thr} 218(2.132 \AA)\end{array}$ \\
\hline
\end{tabular}

Based on the statistical results, the compounds which have similar amino acid residues closest to KNI-10006 are ganodermanondiol and ganolucidic acid A, results of p-value less than 0.05 indicates significant results. Cohen's Cappa measurement results ganodermanodiol showed affinity with substantial level of agreement whereas for ganolucidic acid A showed affinity with moderate levels of agreement. The compounds that least like are ganoderat acid $\mathrm{B}$ and ganoderat acid $\beta$, results of $\mathrm{p}$-value more than 0.05 indicates that the results are not significant. Cohen's Cappa measurement results two compounds showed affinity with a fair level of agreement. 
Table 5. Association Coefficient, Agreement and Inter-Rater Reliability Amino Acid of the Ligands with KNI-10006

\begin{tabular}{lccc}
\hline \multirow{2}{*}{ Ligand } & \multicolumn{2}{c}{ Correlation* } & Proximity** \\
\cline { 2 - 4 } & Cramer's V & P & Kappa \\
\hline Ganolucidic acid A & 0.57 & 0.002 & $0.54(95 \% \mathrm{CI}:[0.21,0.86])$ \\
Ganoderat acid B & 0.30 & 0.125 & $0.29(95 \% \mathrm{CI}:[-0.08,0.67])$ \\
Ganoderat acid $\beta$ & 0.30 & 0.125 & $0.29(95 \% \mathrm{CI}:[-0.08,0.67])$ \\
Ganodermanondiol & 0.62 & 0.0009 & $0.61(95 \% \mathrm{CI}:[0.30,0.92])$ \\
\hline * Relation coefficient was calculated based on Cramer's V association compared with the amino acid residues from re-docking of \\
KNI-10006. \\
** Proximity is calculated based on Cohen's Kappa method compared with the amino acid residues from re-docking of KNI-10006.
\end{tabular}

\section{Conclusion}

The binding modes of ganolucidic acid A, ganoderat acid B, ganoderat acid $\beta$ and ganodermanondiol, triterpenoids of G. lucidum, resemble that of KNI-00006, a known inhibitor of PM I, while according to the predicted $\mathrm{Ki}$ of the ligands, ganoderat acid $\mathrm{B}$ showed better affinity towards HIV-1 PR than nelfinavir. These compounds could be developed further as both anti-HIV and anti-malaria.

\section{References}

Banerjee, R., Liu, J., Beatty, W., Klemba, M., \& Goldberg, D. E. (2002). Four plasmepsins are active in the Plasmodium falciparum food vacuole, including a protease with an active-site histidine, Proc Natl Acad Sci USA, 99(2), 990-995. http://dx.doi.org/10.1073/pnas.022630099

Bhaumik, P., Gusthina, A., \& Wlodawer, A. (2011). Crystal structure of KNI-10006 complex of Plasmepsin I (PMI) from Plasmodium falciparum. J.Struct.Biol., 175, 73-84. http://dx.doi.org/10.1016/j.jsb.2011.04.009

Colin, B., Humphreys, M. J., Matharu, P., Granger, R., Horrocks, P., \& Moon, R. P. (1999). A distinct member of the aspartic proteinase gene family from the human malaria parasite Plasmodium falciparum. FEBS Lett, 447,149-154.

Hou, T., McLaughlin, W. A., \& Wang, W. (2008). Evaluating the Potency of HIV-1 Protease Drugs to Combat Resistence. Proteins, 71(3), 1163-1174. http://dx.doi.org/10.1002/prot.21808

Jaskólski, M., Tomasselli, A. G., Sawyer, T. K., Staples, D. G., Heinrikson, R. L., Schneider, J., Kent, S. B., et al. (1991). Structure at 2.5-A resolution of chemically synthesized human immunodeficiency virus type 1 protease complexed with a hydroxyethylene-based inhibitor, Biochemistry, 30(6), 1600-1609.

King, N. M., Prabu-Jeyabalan, M., Bandaranayake, R. M., Nalam, M. N., Nalivaika, E. A., Ozen, A., Yilmaz, N. K., \& Schiffer, C. A. (2012). Extreme entropy-enthalpy compensation in a drug-resistant variant of HIV-1 protease. Acs Chem Biol, 7, 1536-1546. http://dx.doi.org/10.1021/cb300191k

Levita, J., Heng, C., \& Mutakin, K. (2014). Interactions of ganoderiol-f with aspartic proteases of HIV and plasmepsin for anti-HIV and anti-malaria discovery. International Journal of Pharmacy and Pharmaceutical Science, 6(5), 561-566. http://www.ijppsjournal.com/Vol6Issue5/9474.pdf

Northrop, D. B. (2001). Follow the protons: a low-barier hydrogen bond unifies the mechanisms of the aspartic proteases. Acc Chem Res, 34(10), 790-797.

Parikh, S., Gut, J., Istvan, E., Goldberg, D. E., Havlir, D. V., \& Rosenthal, P. J. (2005). Antimalarial activity of human immunodeficiency virus type 1 protease inhibitors. Antimicrob Agents Chemother, 49, $2983-2985$. http://dx.doi.org/10.1128/AAC.49.7.2983-2985.2005

Savarino, A., Cauda, R., \& Cassone, A. (2005). Aspartic proteases of Plasmodium falciparum as the target of HIV-1 protease inhibitors, J Infect Dis, 191, 1381-1383. http://dx.doi.org/10.1086/428781

WHO. (2014). MDG 6: combat HIV/AIDS, malaria and other diseases. Tersedia di: http://www.who.int/topics/millennium_development_goals/diseases/en/ [Accessed on 18th June 2014]

\section{Copyrights}

Copyright for this article is retained by the author(s), with first publication rights granted to the journal.

This is an open-access article distributed under the terms and conditions of the Creative Commons Attribution license (http://creativecommons.org/licenses/by/3.0/). 